\title{
Observations on the Feeding Behavior of the Semifossorial Snake Ninia atrata (Hallowell 1845) (Serpentes: Dipsadidae)
}

Julián Andrés Rojas-Morales ${ }^{1,2}$, Juan Camilo Zuluaga-Isaza ${ }^{3}$, Román Felipe Díaz-Ayala ${ }^{3}$

${ }^{1}$ Instituto de Ciencias Ambientales y Ecológicas, Facultad de Ciencias, Universidad de Los Andes, Mérida, Venezuela (julian.herpetologia@gmail.com) ${ }^{2}$ Research Associate, Museo de Historia Natural, Centro de Museos Universidad de Caldas, Manizales, Caldas, Colombia ${ }^{3}$ Grupo de Ecología y Diversidad de Anfibios y Reptiles, Facultad de Ciencias Exactas y Naturales, Universidad de Caldas, Calle 65 \#26-10, Manizales, Colombia

Some small-bodied terrestrial and semifossorial Neotropical snakes (e.g., Atractus, Geophis, Ninia) exhibit a poorly documented feeding strategy based on the consumption of small soft-bodied invertebrates such as slugs (Mollusca: Gastropoda) and earthworms (Annelida: Oligochaeta). They often are referred to as goo-eaters (Cadle and Greene 1993; Cundall and Greene 2000; Savage 2002; Zaher et al. 2014).

Snakes of the genus Ninia Baird and Girard 1853 are small, semifossorial, distributed throughout the Neotropics (Savage 2002; Angarita-Sierra 2014), and have a Mesoamerican origin (Savage 1966; Duellman 1990; Cadle and Greene 1993). These snakes represent an important component within some Neotropical herpetofaunal assemblages due to their local abundance (Savage and Lahanas 1991; Savage 2002) even in modified environments (Angarita-Sierra 2015; Lynch 2015).

The South American Coffee Snake or Red-naped Snake, Ninia atrata (Hallowell 1845), ranges from northern South America to Panama, including the islands of Trinidad and Tobago (McCranie and Wilson 1985; Savage 2002; AngaritaSierra 2009, 2014). This species has been the subject of studies on hemipenial morphology, phylogeny, taxonomy, and geographic variation (McCranie and Wilson 1995; Ingrasci 2011; Angarita-Sierra 2009, 2014), and AngaritaSierra (2015) described its repertoire of defensive behaviors. However, some of its basic natural history, including its reproductive cycle, diet, and patterns of activity, remains unknown. Herein we present a field observation of feeding behavior of N. atrata on earthworms (Annelida: Oligochaeta) in the middle Magdalena River Valley, Colombia.

At $1150 \mathrm{~h}$ on 10 March 2014, we found an individual (SVL $246 \mathrm{~mm}$, tail length $60 \mathrm{~mm}$ ) hidden in dry leaf litter within a 25-year-old secondary forest at "La Campiña," near the village of Confines, Municipality of Samaná, Department of Caldas, Colombia (5'29'41.6”'N, 7454'39.1'W, WGS84, elevation $480 \mathrm{~m}$ asl). A day later, when the snake was released, we found two earthworms in the upper layer of soil under the litter and offered them to the snake in order to observe the capture, manipulation, and ingestion of prey. On a patch of bare ground $\left(<1 \mathrm{~m}^{2}\right)$, we held the snake by the posterior part of the body before releasing it $15-30 \mathrm{~cm}$ from the live earthworms, which were moving on the surface. After five repetitions during which the snake passed over the earthworms, it reacted to their presence. The snake paused and bent its head over one earthworm, tongue-flicking rapidly before attacking (Fig. 1A). After capture, the snake moved its head from side to side, alternately opening and closing its mouth and independently moving each lower jaw, effectively rotating the worm along its axis until reaching one of its extremes (Fig. 1B-C). Immediately after ingesting the first earthworm, the snake turned its attention to the other worm and consumed it in the same manner. The capture, manipulation, and ingestion of both earthworms was fast $(<60 \mathrm{sec}$ each), and the worms were alive throughout the process. The snake also swallowed bits of soil stuck to the bodies of the earthworms. We subsequently released the snake at the site.

Although the frequency of published accounts of snake predation in the field has increased considerably in recent decades, the feeding behavior of most species remains undescribed. Greene (1975), Cadle (1992), and Savage (2002) recorded the consumption of earthworms by snakes in the genus Ninia, and Cadle and Greene (1993) related this to a specialized feeding strategy (Cadle and Greene 1993), although beetle remains, caecilians, slugs, and small snails have been found in stomach contents of $N$. psephota and N. sebae (Slevin 1942; Greene 1975). Cundall and Greene (2000) assigned earthworms to a Type IIa prey, which corresponds to elongated and limbless animals of small diameter that do not require a wide buccal opening for capture and ingestion. In addition, earthworms are easily captured prey, 

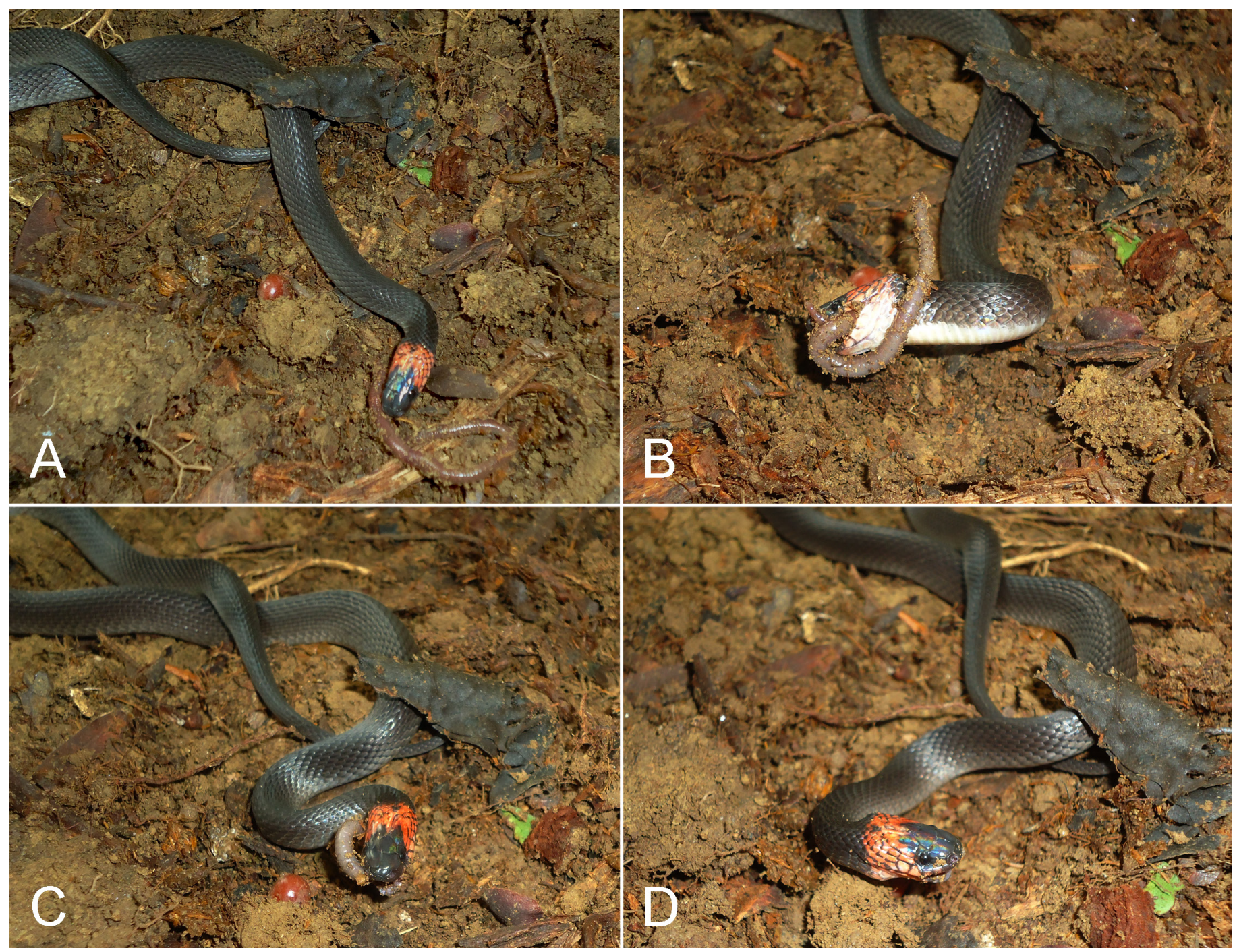

Fig. 1. Predation by a South American Coffee Snake, Ninia atrata (SVL 246 mm, TL $60 \mathrm{~mm}$ ) of an earthworm (Annelida: Oligochaeta): (A) Detection of prey; (B-C) manipulation and ingestion; and (D) mandibular realignment. Photographs by Román Felipe Díaz-Ayala.

and lack the capability of inflicting damaging or fatal wounds to snakes when captured.

Ninia atrata is likely an important predator of earthworms at sites where the species reaches high population densities. Lynch (2015) recorded 145 individuals during 26 days of sampling in a natural habitat and an oil palm plantation in the Department of Meta, Colombia; he suggested that the abundance of snakes observed, including $N$. atrata, might depend on the abundance of earthworms and other potential soft-bodied prey, basing that hypothesis on the lack of success at capturing snakes in areas lacking appreciable quantities of prey.

\section{Acknowledgements}

We thank the Universidad de Caldas and ISAGEN for funding fieldwork during the project "Monitoreo de la fauna vertebrada silvestre en zonas de influencia de los centros productivos de ISAGEN en el oriente de Caldas" (Contract 47/180).
We also thank Juan Carvajal Cogollo (Instituto de Ciencias Naturales, Universidad Nacional de Colombia) and Teddy Angarita Sierra (Yoluka ONG) for helpful comments on a previous draft of this manuscript.

\section{Literature Cited}

Angarita-Sierra, T. 2009. Variación geográfica de Ninia atrata en Colombia (Colubridae: Dipsadinae). Papéis Avulsos de Zoologia 49: 277-288.

Angarita-Sierra, T. 2014. Hemipenial morphology in the semifossorial snakes of the genus Ninia and a new species from Trinidad, West Indies (Serpentes: Dipsadidae). South American Journal of Herpetology 9: 114-130.

Angarita-Sierra, T. 2015. Repertoire of antipredator displays in the semifossorial snake Ninia atrata (Hallowell, 1845) (Serpentes: Dipsadidae). Herpetology Notes 8: 339-344.

Cadle, J.E. and H.W. Greene. 1993. Phylogenetic patterns, biogeography, and the ecological structure of Neotropical snake assemblages, pp. 281-293. In: R.E. Ricklefs and D. Schluter (eds.), Species Diversity in Ecological Communities. The University of Chicago Press, Chicago, Illinois.

Cundall, D. and H.W. Greene. 2000. Feeding in snakes, pp. 293-333 In: K. Schwenk (ed.), Feeding: Form, Function, and Evolution in Tetrapod Vertebrates. Academic Press, San Diego, California. 
Duellman, W.E. 1990. Herpetofauna in Neotropical rainforests: Comparative composition, history, and resource use, pp. 455-505. In: A.H. Gentry (ed.), Four Neotropical Rainforests. Yale University Press, New Haven, Connecticut.

Greene, H.W. 1975. Ecological observations on the Red Coffee Snake, Ninia sebae, in southern Veracruz, Mexico. The American Midland Naturalist 93: 478-484.

Ingrasci, M.J. 2011. Molecular systematics of the coffee snakes, genus Ninia (Colubridae: Dipsadinae). Unpublished MS Thesis, University of Texas, Arlington.

Lynch, J.D. 2015. The role of plantations of the African Palm (Elaeis guineensis Jacq.) in the conservation of snakes in Colombia. Caldasia 37: 169-172.

McCranie J.R. and L.D. Wilson. 1995. Two new species of colubrid snakes of the genus Ninia from Central America. Journal of Herpetology 29: 224-232.

Savage, J.M. 1966. The origins and history of the Central American herpetofauna.
Copeia 1966: 719-766.

Savage, J.M. 2002. The Amphibians and Reptiles of Costa Rica: A Herpetofauna between Two Continents, between Two Seas. The University of Chicago Press, Chicago, Illinois.

Savage J.M. and P.N. Lahanas. 1991. On the species of the colubrid snake genus Ninia in Costa Rica and western Panama. Herpetologica 47: 37-53.

Slevin, J.R. 1942. Notes on a collection of reptiles from Boquete, Panama, with the description of a new species of Hydromorphus. Proceedings of the California Academy of Sciences ser. 4, 23: 463-480.

Zaher, H., L. Oliveira, F.G. Grazziotin, M. Campagner, C. Jared, M.M. Antoniazzi and A.L. Prudente. 2014. Consuming viscous prey: A novel protein-secreting delivery system in Neotropical snail-eating snakes. BMC Evolutionary Biology 14: 58. 